Accepted version of the following book chapter:

https://link.springer.com/chapter/10.1007/978-3-319-42271-8_5

\title{
Defaunation through the eyes of the Tsimane'
}

\author{
Álvaro Fernández-Llamazares, Isabel Díaz-Reviriego and Victoria Reyes-García
}

\begin{abstract}
Defaunation is one of the most critical challenges faced by contemporary hunter-gatherers worldwide. In the present chapter we explore how this global anthropogenic phenomenon is being explained by a hunter-gatherer society: the Tsimane' of Bolivian Amazonia. First, we briefly review the historical context of contemporary Tsimane', with a special focus on defaunation trends in their territory. We then draw on ethnographic accounts to understand how this society explains the drivers of defaunation and integrates them in their understanding of the world, and specifically in their mythology. The Tsimane' perceive widespread defaunation in their territory, which they tend to largely interpret as a result of both natural and supernatural forces, with intertwined arguments. The Tsimane' think that supernatural deities control animals, and consequently they associate wildlife scarcity with punishments by the spirits in response to disrespectful conducts. As such, defaunation is interpreted as a consequence of (a) direct harm to wildlife population by the inappropriate hunting and fishing behaviour; and (b) the discontentment of the animal deities for not respecting certain established cultural norms. The latter is also aggravated by the Tsimane' recent relative inability to communicate with the spirits, due to the disappearance of shamans. Considering that the way people interpret environmental change can determine their behaviour towards proposed conservation actions, understanding the symbolic dimensions of defaunation is of direct relevance to any initiative aiming for sustainable wildlife management in areas inhabited by hunter-gatherers.
\end{abstract}

\subsection{Introduction}

Human-animal interactions are at the core of contemporary hunter-gatherers' cultural identity (Denevan 1980; Kelly 1995; Schweitzer et al. 2000). Across the Amazonian Basin, representations of animals are deeply rooted in the culture and history of many hunter-gatherer groups, with numerous legends, rituals and beliefs emphasizing the critical role of animals in the sustenance of their livelihoods (Cormier 2006; Good 1989). Given that nature-culture interactions are inherently co-evolutionary (Berkes et al. 2000; Posey 1985), researchers have addressed both how cultural practices referring to animals (e.g., norms or taboos) shape the way in which hunter-gatherers manage animal populations and adapt to game scarcity (Ross et al. 1978; Virtanen et al. 2009, 2012), and how local wildlife changes are represented in the cultural expressions of hunter-gatherers, such as for example in their myths, customs and traditions (Fausto 2008; Luz 2013; Shepard Jr 2002).

\footnotetext{
Á. Fernández-Llamazares (corresponding author) · Isabel Díaz-Reviriego · Victoria Reyes-García Metapopulation Research Centre, Department of Biosciences P.O. Box 65 (Viikinkaari 1)

FI-00014 - University of Helsinki, Helsinki, Finland

Email: alvaro.fernandez-llamazares@helsinki.fi
} 
However, under the context of Global Environmental Change, the livelihoods and cultures of contemporary hunter-gatherers are under exceptionally great pressure (Maru et al. 2014; Pringle 2015; Weatherhead et al. 2010), also affecting human-animal interactions. Throughout Amazonia, economic processes resulting in land-grabbing, colonisation, the advance of extractive industries, deforestation, habitat loss and climate change are all dramatically altering the access that hunter-gatherers have to their surrounding environment and resources, including animals (see for example Espinosa et al. 2014; Finer et al. 2015). Similarly, cultural processes such as access to western-style education and health, the adoption of national languages, access to mass media or religious expansion are also dramatically changing the way in which indigenous peoples understand the world (Doughty et al. 2010; Reyes-García et al. 2014a).

From the many changes affecting hunter-gatherers, defaunation, defined as the loss of wildlife, including species and populations (Dirzo et al. 2014:401), has arguably a huge impact on the livelihood of hunter-gatherer populations. This is largely due to the importance of animals for their sustenance (Alvard 1993; Mena et al. 2000). In Amazonia, hunting and fishing are not only the primary source of protein and hence critical to human health, but also fundamental metaphors that structure the relation between hunter-gatherers, animals and the spiritual world (Århem 1996; Fausto 2007; Reichel-Domatoff 1976). As a result, changes in the availability and/or distribution of wild animals are often quickly perceived and interpreted in spiritual terms (Virtanen, this volume). Studying such interpretations is important because they shape how people might respond to the impending changes. Furthermore, such interpretations might have direct implications for the maintenance of the livelihood strategies of contemporary hunter-gatherers (Fernández-Llamazares et al. 2015a). For this reason, the symbolic dimensions of defaunation can be of direct relevance to any initiative aiming for sustainable wildlife management and biodiversity conservation in areas inhabited by hunter-gatherers (Franzen 2005; Lu 2001).

Here we illustrate how defaunation alters the way a hunter-gatherer group, the Tsimane' of Bolivian Amazonia, perceive the reality. First, we briefly review the historical and ecological context of contemporary Tsimane', with a special focus on defaunation trends in their territory. We then draw on our ethnographic work on the area to understand how the Tsimane' explain the drivers of defaunation, and how the phenomenon is made culturally relevant through its integration into Tsimane' mythological stories. For the purposes of this chapter, we reviewed classical ethnographies to understand the role of wildlife, specifically game and fish, in Tsimane' mythology. Furthermore, we present results from our own ethnographic work in the area, as part of a research project conducted over the course of three years (2012-2015; see http://icta.uab.cat/Etnoecologia/lek). We draw on our extensive participation in Tsimane' daily activities and on informal interviews that we conducted with both Tsimane' villagers and local political authorities to compile information on how Tsimane' perceive recent defaunation trends. We also include information on Tsimane' conceptions of defaunation collected through in-depth interviews and focus groups about Tsimane' perceptions of changes in wildlife (game and fish species) and their explanations for such changes (see Fernández-Llamazares et al. 2015a for a complete description of the methodology and results).

The Tsimane' provide an interesting case to study the local interpretations and explanations of defaunation for three reasons. First, having remained isolated until the mid- $20^{\text {th }}$ century, a large part of their traditional beliefs still persists nowadays. Second, their territory is being increasingly affected by considerable levels of pervasive environmental change, including defaunation (Fernández-Llamazares et al. 2015b; 
Pérez-Llorente et al. 2013). And third, with the scientific discourse on anthropogenic Global Environmental Change being still largely inaccessible to this group (FernándezLlamazares et al. 2015c), the Tsimane' understandings of defaunation are most probably conferred to local manifestations of such phenomenon and based on their cultural epistemologies.

\subsection{The Tsimane' of Bolivian Amazonia}

\subsubsection{Cultural and historical context}

The Tsimane' are a native Amazonian society living in the south-western department of Beni, Bolivian Amazonia. Nowadays, they number approximately 14,000 people (Undurraga et al. 2014) living in some 125 villages of commonly ca. 20 households per village, mostly concentrated along riverbanks and logging roads (Reyes-García et al. 2012). Traditionally, the Tsimane' were hunter-gatherers and fishers, but nowadays they also practise small-scale shifting agriculture (Vadez and Fernández-Llamazares 2014). Furthermore, some Tsimane' (particularly those in villages close to market towns) are starting to engage in cash-generating activities such as cash cropping (mostly rice and plantain), sale of non-timber forest products (e.g., thatch palm), and wage labour in logging camps and cattle ranches (Fernández-Llamazares et al. 2015b; Reyes-García et al. 2014b). Despite these new sources of income and livelihood, the forests continue to provide an essential basis for Tsimane' subsistence activities (Fernández-Llamazares et al. 2015b; Reyes-García et al. 2014a).

Historical accounts of the Tsimane' depict them as a particularly elusive ethnic group (Chicchón 1992; Nordenskiöld 1924; Pauly 1928). Escaping from the violence and abuses of the Hispanic conquests, the Tsimane' confined themselves to the remote upper parts of the Apere and Maniqui Rivers (Reyes-García et al. 2014a). Hidden in 'almost impenetrable forests' (Pauly 1928:116), the Tsimane' succeeded in resisting Catholic and Protestant proselytes' incursions from the early seventeenth century up until the 1950s (Martínez-Rodríguez 2009; Pérez-Díez 1983). Ethnographic works also describe the Tsimane' as being a highly mobile society, with dispersed settlement patterns and lacking a hierarchical system of authority (Califano 1975; Daillant 2003; Ellis 1996), possibly explaining why they managed to withstand the evangelisation process and remain relatively isolated until the mid- $20^{\text {th }}$ century. Moreover, living in a land lacking the commercial resources valued by Europeans (i.e., gold, silver and rubber trees), the Maniqui and Apere Basins provided the perfect hideout for the Tsimane' to resist the whirlpool of conquest and illnesses brought by the arrival of colonists elsewhere in the region.

Thus, up until the late 1930s, the Tsimane' largely maintained a semi-nomadic and self-sufficient lifestyle, keeping occasional and selective contact with outsiders (Nordenskiöld 1924; Pauly 1928). Moreover, the little contact that did take place has been attributed to the Tsimane' interest in market goods such as clothes and metal utensils like axes, knives and fishhooks (Nordenskiöld 1924). However, after the 1952 Bolivian Revolution, the construction of new roads, the logging boom, the land tenure reforms and the different waves of government-planned Andean colonisation of the Bolivian lowlands pushed the Tsimane' into increasing contact with other segments of the national society (Reyes-García et al. 2012, 2014a). This period also saw the onset of the trade in animal pelts, an activity in which Tsimane' actively participated. Local ranchers and colonists started to pay low salaries to the Tsimane' for tracking wild animals such as black caimans (Melanosuchus niger), tapirs (Tapirus terrestris), and white-lipped peccaries (Tayassu pecari). Several authors had reported that trade of 
animal pelts had important repercussions on animal populations, with some of the most precious species eventually becoming locally depleted (Herrera-MacBryde et al. 2000; Luz 2013; Roca 2001). Finally, the settlement of evangelic missionaries in the area in the 1950s also had profound impacts upon the local culture, replacing many native cultural rituals with Christian practices (Huanca 2008, 2014). Today, the beliefs held by most Tsimane' represents a syncretic blend of animist beliefs and those brought by Christian missionaries (Ellis 1996; Fessler et al. 2015).

\subsubsection{Tsimane' relation with wildlife and the natural environment}

As other Amazonian groups (Descola 2005; Virtanen, this volume), the Tsimane' see human beings as part of the natural world, which is inhabited by animals, spirits and human beings altogether. This is reflected in different features of Tsimane' culture, such as their numerous hunting and fishing rules, customs and taboos, which are intended to respect the wellbeing of animals and promote a harmonious relation with the spirits (Chicchón 1992; Huanca 2008). The Tsimane' are (partially) animists and believe that they share their territory with a number of spirits ( $a$ 'mo') who 'own' trees, stones, water bodies, animals and animal breeding grounds. The Tsimane' show reverential attitudes towards these spirits, because -in their view- these spirits can interfere with their daily life, for example causing sickness or controlling game and fish availability (ReyesGarcía 2001; Riester 1976). Consequently, the Tsimane' have specific rules and rituals to regulate their behaviour in relation to resources protected by spirits, such as wildlife. For instance, Tsimane' hunters often pray to the animal masters before hunting, asking them to provide enough meat to sustain their families. Taboos regulating hunting behaviour, such as the interdiction to hunt for those having had sexual intercourse, or micdyidye', can also be interpreted as a way to regulate the time between hunting expeditions. Again, according to the Tsimane', neglecting to follow these rules has negative consequences for the Tsimane', since the spirits have the power to protect or harm humans, depending on their behaviour (Chicchón 1992; Luz 2013).

One of the many Tsimane' wildlife-related mythological stories recounts the story of Jäjäbä, the main guardian of game. Jäjäbä is considered the master of animals, responsible for taming, caring and managing the flock of wild animals (Huanca 2014). The Tsimane' see Jäjäbä as a shepherd or cattle owner. The guardian owns a large farm where he keeps, feeds, breeds and herds wild animals. Jäjäbä periodically opens the door of the farmyard and releases his herds so that the Tsimane' can hunt. According to Tsimane' beliefs, Jäjäbä has the power to nurture and endanger human life. He controls the supply of game, and can easily get angered by inappropriate human actions, e.g., those that drive away or hurt the animals (Ellis 1996). For instance, if a hunter did not treat animals with respect, Jäjäbä may bewitch him, cause illness to his family, or deprive the community of game by not opening the doors of the farm. According to the words of a Tsimane' elder, in cases of misbehaviour, "Jäjäbä would take all the animals from the forest" (Luz 2013:22). In other words, lack of compliance with the demands of $J \ddot{a j a ̈ b} \ddot{a}$, e.g. by not following well-established cultural practices (e.g., asking permission before killing an animal) could break down the balance between people and supernatural beings, with pernicious consequences for humans. Given its enormous power, the Tsimane' consider it crucial to negotiate with Jäjäbä before engaging in hunting.

Similarly, the Tsimane' have a myth that tells of access to fish. According to Tsimane' mythology, fish availability is regulated by human interactions with two fish deities: I'dojore and O'pito (Chicchón 1992; Díaz-Reviriego et al. submitted). I'dojore is a beneficent spirit who provides the Tsimane' with fish when they are in need, 
whereas O'pito is a harmful owner who controls fish resources, monopolising without sharing them, and thus causing fear and distrust amongst the Tsimane' (Chicchón 1992). Moreover, O'pito is responsible for watching and managing the periodic movements of migratory fish along the river (Huanca 2014). Like Jäjäbä, O'pito has the power to bewitch people if they disobey his rules, particularly when he carries the fish upriver. Because of O'pito's frightening powers, the Tsimane' are afraid to fish in excess during the periods when fish migrate upriver. Our interpretation of the myth is that the portrayal of O'pito as a frightful and appalling spirit responds to the importance of allowing migratory fish to move unimpeded through waterways in order to maintain healthy fish populations all along the river and prevent fish stock declines.

\subsubsection{The shamans as mediators between humans and spirits}

While spirits could observe and act upon humans, humans required a mediator to communicate with the supernatural world, a role that traditionally corresponded to the figure of the shaman (cocojsi') (Huanca 2014). Although research on Tsimane' shamanism is scarce, previous ethnographic works suggest that shamans were relatively common in the Tsimane' villages prior to the arrival of missionaries to the area in the 1950s (Huanca 1999, 2008). Shamans performed a variety of functions, including folk healing (particularly administering plant treatments for sorcery and bewitchment), storytelling, and enforcing law and order. Shamans were also in charge of teaching and reminding that wild animals, as well as plants and other natural features, deserved respect and required worship. They were also responsible for communicating with the wildlife spirits on behalf of the whole community. Through chanting in the ritual house (shipa) the shaman implored the spirits to supply animals for the Tsimane', who in turn offered fermented beer made from manioc (shocdye') to the owner of the animals. Tsimane' people understand that killing animals requires a reciprocal relation, so they compensate the master of animals by providing shocdye' in appreciation of the meat. The shaman would also offer payments (e.g., duck eggs or coins) to the animal masters, in order to reinforce the alliance between humans and spirits (Århem 1996). Such payments were dedicated to the owners of the animals as a way of thanking them for having supplied wildlife.

As with other Amazonian native groups (e.g., Reichel-Dolmatoff 1999), the shamans in the Tsimane' society also acted as managers of wildlife stocks. The shamanic rituals provided the Tsimane' with the opportunity to communicate with the spirits in critical times (e.g., during periods of game scarcity). If game was scarce, the shaman would call Jäjäbä to the ritual house and beg him to supply animals. According to Huanca (2008), the Tsimane' would get answers from supernatural beings, and modify their hunting behaviour accordingly. In the shamanic rituals, Jäjäbä would come, speak sharply, and say "you are annoying my animals" (Huanca 2008:151). Then the shaman would negotiate with the animal guardian and ask for forgiveness, in order to re-establish the reciprocal pact established between humans and spirits (Århem 1996). In other words, the shaman was responsible for alleviating the tensions that could arise between humans and spirits when the animal master's rules were not obeyed and/or respected. Moreover, the shaman was also able to impose restrictions on the amount of game that the community or a specific hunter could hunt, in order to please the spirits (Huanca 2008). For example, it was common that for certain species, such as the spider monkey (Ateles chamek) or the white-lipped peccary (Tayassu pecari), the Tsimane' could only capture one animal per hunting trip, as prescribed by the shaman (Luz 2013). 
Similarly, shamans would also mediate the relation between Tsimane' and the fish masters. In Tsimane' oral accounts, the shamans guided people to find fish and prepared them to meet the fish owners. The shaman actively encouraged to follow the rules of O'pito, so that the spirit did not kill or bewitch people. If someone captured excess fish or interrupted their migratory movements, $O$ 'pito would get angry and use sorcery to bring illness and death (Huanca 2008). Similarly, I'dojore used to warn the Tsimane' about the allowed fishing quotas. For example, oral accounts describe how I'dojore would join the Tsimane' in their shamanic rituals and warn them with statements such as "If you want fish, you must not fish too much or throw away what you have fished" (Huanca 2014:347). Through his teachings, the shaman might have contributed to protect the fish stocks in the Maniqui River.

Due to strong influence of the missionaries from the 1950s onwards, Tsimane' shamans do not exist anymore. The last shaman passed away three decades ago. Although some of their descendants, assistants, and some local elders still sporadically exercise some of their functions (mostly plant treatments), they rarely mediate between humans and the spirits (Huanca 2014).

\subsection{Defaunation in the Tsimane' territory}

\subsubsection{Scientific evidence of defaunation}

The above-mentioned socio-economic and cultural transformations, combined with substantial environmental changes in the Tsimane' territory (Fernández-Llamazares et al. 2015a,b; Pérez-Llorente et al. 2013; Ringhofer 2010), have all contributed to the rapid decline in biodiversity recurrently reported in the area. Such decline mostly stems from significantly high levels of deforestation, habitat loss, and hunting pressures (Guèze et al. 2014; Luz et al. in press; Paneque-Gálvez et al. 2013). Concomitantly, defaunation has become an important threat, with some authors describing the Tsimane' territory as suffering an 'empty forest syndrome' (Chicchón 1992; Luz 2013; Ringhofer 2010). Indeed, an exhaustive analysis of published research in the area provides evidence of substantial faunal changes at the local level (Fernández-Llamazares et al. 2015a). For example, Luz (2013) found that overall, the vertebrate fauna in the Tsimane' territory is less diverse (in terms of number of species) than in other terra firme Amazonian forests also subject to hunting pressure (Endo et al. 2010; Peres 1997). Thus, the author found that encounter rates of large-bodied species (e.g., Tayassu pecari) assessed in $2.6 \mathrm{~km}$ transects in 40 Tsimane' villages were on average lower than the ranges described for other hunting forest sites in Amazonia (Luz 2013).

In general, most of the game species culturally-valued by the Tsimane' are in high risk of endangerment, with significant rates of population decline and fragmented distributions (Fernández-Llamazares et al. 2015a; Luz et al. in press). The spider monkey (Ateles chamek), a favourite game species for the Tsimane' (Chicchón 1992), is now classified as a vulnerable species (IUCN 2014). Likewise, the giant anteater (Myrmecophaga tridactyla), the giant armadillo (Priodontes maximus), and the lowland tapir (Tapirus terrestris) are all catalogued as vulnerable according to the Bolivian Red List (MMA 2009). Most of the population trends for these species are considered to be decreasing due to overhunting and habitat loss (IUCN 2014). Such impacts are amplified by the low ability of some species (e.g., Tapirus terrestris) to quickly repopulate the areas where they previously lived. Fernández-Llamazares et al. (2015a) reported that the status of the above-mentioned species has deteriorated in the Tsimane' territory since previous IUCN Red List assessments. 
Similarly, local extirpation of valued fish species, as well as changes in freshwater communities (e.g., reduction of fish population sizes and alteration of age structure) are also widely reported in the area (Díaz-Reviriego et al. submitted; Pérez 2001; Zycherman 2013). Overall, it is likely that the Maniqui River is affected by overfishing, or what is referred to by some as 'fishing down the foodweb', a process by which the largest species from the top of the food web are depleted, leading to successive pressure down the food web to smaller sized fish species (Castello et al. 2013). Although the Tsimane' fish all year round, there is significant seasonal variation due to the fact that several of the fish species targeted by the Tsimane' are migratory (e.g., large-bodied catfishes and the golden dorado). These species migrate from the lowlands to the headwaters of the Maniqui River for spawning, a general pattern observed in response to the annual hydrological regime occurring in large rivers across the Amazonian Basin (Cañas and Pine III 2011; Junk and Wantzen 2004). Widespread fishing during the fish migration periods interrupts the biological cycle of many species and causes stock declines (Salo et al. 2014). The Tsimane' report that at least five fish species have become locally-extinct in the Maniqui River (Fernández-Llamazares et al. 2015a).

\subsubsection{Tsimane' interpretations of defaunation}

It is clear that the Tsimane' identify a wide array of local indicators of a handful of environmental changes occurring in their territory, including climate change, deforestation and notably, widespread and pervasive defaunation (FernándezLlamazares et al. 2015a). Recent research has found that the Tsimane' report wildlife scarcity (including game and fish) when comparing present with past times (FernándezLlamazares et al. 2015a; Zycherman 2013). The Tsimane' report large differences between the composition of those game species perceived as more abundant in the past and those perceived as more abundant in the present. In general, Tsimane' reports of faunal change match relatively well the population trends calculated through the IUCN Red List Index (Fernández-Llamazares et al. 2015a). According to our ethnographic information, in general, the Tsimane' care about wildlife scarcity and, in general, think that they bear certain responsibility for it.

However, the Tsimane' do not conceive changes in the faunal composition and distribution as the consequence of global phenomena or major habitat loss at the regional level. Rather, the Tsimane' tend to consider defaunation as a local phenomenon. In their understanding, animals have not been extirpated, rather they have simply moved away from their territory to other areas. Some Tsimane' elders attribute game scarcity to the fact that the animals might be returning back to the farmyard of Jäjäbä, where they might live far more peacefully than outside. For example, a Tsimane' woman reported "The chainsaw is guilty for the lack of animals. Animals listen to its sound and smell the oil. Since they do not like it, they are going away, leaving back to the original place from where they came" (Woman, 65, June 2013).

According to the Tsimane', local wildlife scarcity is caused by three main drivers, which include natural and supernatural forces that they often present in intertwined arguments. First, many Tsimane' argue that currently experienced animal scarcity is due to the disrespectful attitudes of certain people, whose hunting and fishing behaviour directly harms the wildlife populations. Second, due to such inappropriate conducts, there is widespread discontentment of the animal deities (namely Jäjäbä and O'pito), who could be limiting even more the supply of wildlife. And third, with the disappearance of shamans, they cannot reverse the defaunation trends in their territory and re-establish the reciprocal relationship between humans and spirits. We elaborate on each of these points in the three following paragraphs. 
The Tsimane' are well aware of the impacts of certain hunting and fishing activities upon wildlife. For example, they realize that new hunting technologies such as cartridges, shotguns and headlamps -which are displacing traditional techniques such as crossbows, spears and traditional traps- result in larger game offtake. Similarly, the ability to move faster and further also allows them to reach hunting grounds previously far of reach. The Tsimane' recognise that this technification of hunting has important effects upon wildlife populations. Similarly, the Tsimane' also realize that the use of dynamite for fishing results in the destruction of some of the local fishing grounds. Some Tsimane' disapprove of these techniques (especially the use of dynamite, which is subject to public shaming) because they realize that they result in unsustainable harvest levels and local extirpation of species. It is worth noticing that the Tsimane' often blame outsiders for the use of such aggressive techniques. For example, the Tsimane' argue that dynamite fishing is mostly practised by loggers and merchants. But, through time, some of these techniques are also becoming frequent amongst certain Tsimane' individuals.

According to the Tsimane', with the current erosion of traditional hunting and fishing practices (see Luz 2013 for more examples), there is more likelihood that the animal deities are angry with human beings. It is important to remind that most of the Tsimane' hunting rules are built around the idea of respecting the animals and their well-being. The masters of the animals frown on excessive killing of wildlife by people and might punish them with game scarcity if they do not respect their rules. Consequently, it is not surprising the defaunation is being interpreted in spiritual terms, as a result of the discontentment of animal deities for the use of shotguns and other modern weapons that lead to increased game harvests. Although some Tsimane' feel that disrespecting traditional rules is justified by the imperative need of obtaining food to meet immediate subsistence needs, others expressed to us their concern that these practices could be undermining the mutual pact established between the Tsimane' and the spirits. Most Tsimane' elders still respect many of the traditional norms that regulate adequate hunting and fishing behaviour, and attribute the current game and fish unavailability to the increasing lack of respect towards animals and their spirits, particularly by young generations. For example, a Tsimane' man told us that "The elders are very angry, because the young people do not respect our traditions anymore... Some youngsters do fish with 'palometa' (a modern bow type) and make the fish bleed into the river. They say that this makes the spirits become furious!" (Man, 40, April 2013).

Finally, some Tsimane' also point to the disappearance of shamans as an aggravator of the defaunation trends observed. Many Tsimane' bemoan not having shamans anymore, because their role as mediators was crucial to improve the availability of wild animals. The shaman would ask to the master of the animals to provide game, and then transmit to hunters the location and adequate quota of animals to harvest (Huanca 2008). In the absence of shamans, some elderly people, particularly in villages further from town, still privately chant and blow spells to Jäjäbä asking for wild game to hunt (Huanca 2014), but the idea prevails that communication with the spirits has weakened, worsening even more game scarcity.

\subsection{Concluding remarks}

A review of Tsimane' classical ethnographies and our current research in the area suggests that the Tsimane' do perceive that defaunation is taking place in their territory, a phenomenon that they interpret with the help of their mythological accounts. Wildlife scarcity is generally conceived by the Tsimane' as a consequence of them not having 
respected certain established cultural norms, resulting in direct harm to the wildlife populations, as well as discontentment by the animal deities. The latter is also believed to be exacerbated by the Tsimane' relative inability to communicate with the spirits protecting the animals, due to the disappearance of shamans.

Given that most Tsimane' think that natural and supernatural powers control the relation between humans and nature, it makes sense for them to associate their own hunting and fishing behaviour with rewards and retributions from supernatural spirits. Understanding this connection that the Tsimane' make is important because the way in which people perceive ecological changes determines in great part how they respond to them (Fernández-Llamazares et al. 2015b; Oldekop et al. 2012). At least some of the Tsimane' harvesting and management actions are shaped by their local understandings of defaunation. Hunter-gatherer's perceptions of defaunation can thus play an important role in creating or blocking incentives for the sustainable management of wildlife.

\section{Acknowledgements}

The research leading to these results has received funding from the European Research Council under the European Union's Seventh Framework Programme (FP7/2007-2013) / ERC grant agreement nr. FP7-261971-LEK to V. R.-G. Á.F.-LL was also supported by the Finnish Academy (grant agreement nr. 292765). We thank all the Tsimane' who shared their knowledge and myths with us, the Gran Consejo Tsimane' and CBIDSI for all their support, V. Cuata, S. Fraixedas, S. Huditz, P. Pache, M. Pache, and I.V. Sánchez for all their help during fieldwork, and M. Cabeza,T. Huanca and A. Pyhälä for insightful comments and ideas.

\section{References}

Alvard, M.S. (1993). Testing the "ecologically noble savage" hypothesis: Interspecific prey choice by Piro hunters of Amazonian Peru. Human Ecology, 21, 355-387.

Århem, K. (1996). The cosmic food web: Human-nature relatedness in the Northwest Amazon. In P. Descola \& G. Pálsson (Eds.), Nature and society: Anthropological perspectives (pp. 185-204). London: Routledge.

Berkes, F., Colding, J., \& Folke, C. (2000). Rediscovery of traditional ecological knowledge as adaptive management. Ecological Applications 10(5), $1251-1262$.

Califano, M. (1975). Noticia sobre la prospección etnográfica a los chimane del rio chimane. Scripta Etnologica (Buenos Aires), 3, 195-196.

Cañas, C.M., \& Pine III, W.E. (2011). Documentation of the temporal and spatial patterns of pimelodidae catfish spawning and larvae dispersion in the madre de DiosRiver (Peru): Insights for conservation in the Andean-Amazon headwaters. River Research and Applications, 27(5), 602-611.

Castello, L., McGrath, D.G., Hess, L.L., Coe, M.T., Lefebvre, P.A., Petry, P., Macedo, M.N., Renó, V.F., \& Arantes, C.C. (2013). The vulnerability of Amazon freshwater ecosystems. Conservation Letters, 6(4), 217-229.

Chicchón, A. (1992). Chimane resource use and market involvement in the Beni Biosphere Reserve, Bolivia. PhD Dissertation, University of Florida. 
Cormier, L. (2006). A Preliminary Review of Neotropical Primates in the Subsistence and Symbolism of Indigenous Lowland South American Peoples. Ecological and Environmental Anthropology, 2(1), 14-32.

Daillant, I. (2003). Sens dessus dessous. Organisation sociale et spatiale des Chimane d'Amazonie bolivienne. Nanterre: Société d'Ethnologie.

Denevan, W. (1980). La geografía cultural aborigen de los llanos de Mojos. La Paz: Juventud.

Descola, P. (2004). Las cosmologías indígenas de la Amazonía. In A. Surrallés, \& P. García (Eds.), Tierra Adentro. Territorio indígena y percepción del entorno. Lima: IWGIA.

Descola, P. (2005). Par-delà nature et culture. Paris: Gallimard.

Díaz-Reviriego, I., Fernández-Llamazares, Á., Howard, P.L., Molina, J.L., \& ReyesGarcía, V. (submitted). Fishing in the Amazonian forest: a gendered social network puzzle. Society and Natural Resources. Submitted 20.10.2015.

Dirzo, R., Young, H.S., Galetti, M., Ceballos, G., Isaac, N.J.B., \& Collen, B. (2014). Defaunation in the Anthropocene. Science, 345(6195), 401-406

Doughty, C., Lu, F., \& Sorensen, M. (2010). Crude, Cash and Culture Change: The Huaorani of Amazonian Ecuador. Consilience: The Journal of Sustainable Development, 4(1), 18-32.

Ellis, R. (1996). A taste for movement: An exploration of the social ethics of the Tsimane' of lowland Bolivia. PhD Dissertation, St Andrews University.

Endo, W., Peres, C.A., Salas, E., Mori, S., Sánchez-Vega, J.L., Shepard, G.H., Pacheco, V., Yu, D.W. (2010). Game Vertebrate Densities in Hunted and Nonhunted Forest Sites in Manu National Park, Peru. Biotropica 42(2), 251-261.

Espinosa, S., Branch, L.C., \& Cueva, R. (2014). Road Development and the Geography of Hunting by an Amazonian Indigenous Group: Consequences for Wildlife Conservation. PLoS ONE, 9(12), e114916.

Fausto, C. (2007). Feasting on People: Eating Animals and Humans in Amazonia. Current Anthropology, 48(4), 497-530.

Fausto, C. (2008). Too Many Owners: Mastery and Ownership in Amazonia. Mana: Estudos de Antropologia Social, 14, 329-366.

Fernández-Llamazares, Á., Díaz-Reviriego, I., Luz, A.C., Cabeza, M., Pyhälä, A., \& Reyes-García, V. (2015a). Rapid ecosystem change challenges the adaptive capacity of Local Environmental Knowledge. Global Environmental Change, 31, 272-284.

Fernández-Llamazares, Á., Díaz-Reviriego, I., Guèze, M., Cabeza, M., Pyhälä, A., \& Reyes-García, V. (2015b). Local perceptions as a guide for the sustainable management of natural resources: empirical evidence from a small-scale society in Bolivian Amazonia. Ecology and Society, 21(1), 2. 
Fernández-Llamazares, Á., Méndez-López, M.E., Díaz-Reviriego, I., McBride, M.F., Pyhälä, A., Rosell-Melé, A., \& Reyes-García, V. (2015c). Links between media communication and local perceptions of climatechange in anindigenoussociety. Climatic Change, 131(2), 307-320.

Fessler, D.M.T., Barrett, H.C., Kanovsky, M., Stich, S., Holbrook, C., Henrich, J., et al. (2015). Moral parochialism and contextual contingency across seven societies. Proceedings of the Royal Society B: Biological Sciences, 282(1813), 20150907

Finer, M., Babbitt, B., Novoa, S., Ferrarese, F., Pappalardo, S.E., De Marchi, M., Saucedo, M., \& Kumar, A. (2015). Future of oil and gas development in the western Amazon. Environmental Research Letters, 10, 024003.

Franzen, M. (2005). Huaorani resource use in the Ecuadorian Amazon: hunting, food sharing and market participation. PhD Dissertation, University of California, Davis.

Good, K. (1989). Yanomami Hunting Patterns: Trekking and Garden Relocation as an Adaptation to Game Availability in Amazonia, Venezuela. PhD Dissertation, University of Florida.

Guèze, M., Paneque-Gálvez, J., \& Luz, A.C. (2014). El ambiente natural y la degradación forestal. In V. Reyes-García, \& T. Huanca (Eds.), Cambio global, cambio local. La sociedad tsimane' ante la globalización (pp. 65-89). Barcelona: Icaria Editorial.

Herrera-MacBryde, O., Dallmeier, F., MacBride, B., Comiskey, J.A., \& Miranda, C. (2000). Biodiversity, Conservation and Management in the Region of the Beni Biological Station Biosphere Reserve, Bolivia SI/MAB Ser. Washington, DC: Smithsonian Institution.

Huanca, T. (1999). Tsimane' Indigenous Knowledge, Swidden Fallow Management and Conservation. PhD Dissertation, University of Florida.

Huanca, T. (2008). Tsimane' Oral Tradition, Landscape and Identity in Tropical Forest. La Paz: Imprenta Wagui.

Huanca, T. (2014). La cosmovisión Tsimane' tradicional en un contexto global. In V. Reyes-García, \& T. Huanca (Eds.), Cambio global, cambio local. La sociedad tsimane' ante la globalización (pp. 331-353). Barcelona: Icaria Editorial.

IUCN, International Union for the Conservation of Nature. (2014). The IUCN Red List of Threatened Species. Version 2014.3. http://www.iucnredlist.org. Accessed 3 Mar 2014.

Junk, W.J., \& Wantzen, K.M. (2004). The flood pulse concept: new aspects, approaches and applications - an update. In R.L. Welcomme, \& T. Petr (Eds.), Proceedings of the Second International Symposium on the Management of Large Rivers for Fisheries, volume I (pp. 117-149). Bangkok: FAO-RAP Publications.

Kelly, R.L. (1995). The Lifeways of Hunter-Gatherers. The Foraging Spectrum. New York: Cambridge University Press. 
Lu, F. (2001). The Common Property Regime of the Huaorani Indians of Ecuador: Implications and Challenges to Conservation. Human Ecology, 29(4), 425-447.

Luz, A.C. (2013). The role of acculturation in indigenous people's hunting patterns: Implications for Wildlife conservation. The case of the Tsimane' in the Bolivian Amazon. PhD Dissertation, Universitat Autònoma de Barcelona.

Luz, A.C., Guèze, M., Paneque-Gálvez, J., Pino, J., Macía, M.J., Orta-Martínez, M., \& Reyes-García, V. (in press). How does cultural change affect indigenous peoples' hunting activity? An empirical study among the Tsimane' in the Bolivian Amazon. Conservation and Society.

Martínez-Rodríguez, M.R. (2009). Ethnobotanical knowledge acquisition among Tsimane' children in the Bolivian Amazon. PhD Dissertation, University of Georgia.

Maru, Y.T., Smith, M.S., Sparrow, A., Pinho, P.F., \& Dube, O.P. (2014). A linked vulnerability and resilience framework for adaptation pathways in remote disadvantaged communities. Global Environmental Change, 28, 337-350.

Mena, P., Stallings, J.R., Regalado, J., \& Cueva, R. (2000). The Sustainability of Current Hunting Practices by the Huaorani. In J.G. Robinson, \& E.L. Bennett (Eds.), Hunting for Sustainability in Tropical Forests (pp. 57-78). New York: Columbia University Press.

MMA, Ministerio de Medio Ambiente y Agua de Bolivia. (2009). Libro rojo de la fauna silvestre de vertebrados de Bolivia. La Paz: Ministerio de Medio Ambiente y Agua.

Nordenskiöld, E. (1924). Exploraciones y Aventuras en Suramérica. Santa Cruz de la Sierra: APCOB, Apoyo para el Campesino-Indígena del Oriente Boliviano.

Oldekop, J.A., Bebbington, A.J., Truelove, N.K., Holmes, G., Villamarín, S., \& Preziosi, R.F. (2012). Environmental impacts and scarcity perception influence local institutions in indigenous Amazonian Kichwa communities. Human Ecology, 40, 101-115.

Paneque-Gálvez, J., Mas, J.F., Guèze, M., Luz, A.C., Orta-Martínez, M., Pino, J., Macía, M.J., \& Reyes-García, V. (2013). Land tenure and forest cover change. The case of southwestern Beni, Bolivian Amazon, 1986-2009. Applied Geography, 43, 113-126.

Pauly, A. (1928). Ensayo de etnografía Americana. Viajes y exploraciones. Buenos Aires: Casa Jacobo Peuser

Peres, C.A. (1997). Primate community structure at twenty western Amazonian flooded and unflooded forests. Journal of Tropical Ecology 13(3), 381-405.

Pérez-Díez, A. (1983). Etnografía de los Chiman del Oriente Boliviano. Buenos Aires: University of Buenos Aires. 
Pérez, E. (2001). Uso de la ictiofauna por dos comunidades Tsimane': San Antonio y Yaranda (T. I. Tsimane', Depto. Beni) bajo diferente influencia de Mercado. Bachelor Thesis, Universidad Mayor de San Andrés.

Pérez-Llorente, I., Paneque-Gálvez, J., Luz, A.C., Guèze, M., Macía, M.J., DomínguezGómez, J.A., \& Reyes-García, V. (2013). Changing Indigenous Cultures, Economies, and Landscapes: The Case of the Tsimane', Bolivian Amazon. Landscape and Urban Planning, 120, 147-157.

Posey, D.A. (1985). Indigenous management of tropical forest ecosystems: the case of the Kayapo Indians of the Brazilian Amazon. Agroforestry Systems, 3(2), 139-158.

Pringle, H. (2015). In peril. Science, 348(6239), 1080-1085.

Reichel-Dolmatoff, G. (1976). Cosmology as ecological analysis: A view from the rain forest. Man, 11(3), 307-318.

Reichel-Dolmatoff, G. (1999). A View from the Headwaters. The Ecologist, 29(4), $276-280$.

Reyes-García, V. (2001). Indigenous People, Ethnobotanical Knowledge, and Market Economy. A Case Study of the Tsimane' Amerindians, Bolivia. $\mathrm{PhD}$ Dissertation, University of Florida.

Reyes-García, V., Ledezma, J.C., Paneque-Gálvez, J., Orta-Martínez, M., Guèze, M., Lobo, A., Guinart, D., \& Luz, A.C. (2012). Presence and Purpose of Nonindigenous Peoples on Indigenous Lands: A Descriptive Account from the Bolivian Lowlands. Society and Natural Resources, 25(1-3), 270-284.

Reyes-García, V., Paneque-Gálvez, J., Guèze, M., Luz, A.C., Macía, M.J., OrtaMartínez, M., \& Pino, J. (2014a). Cultural Change and Traditional Ecological Knowledge: An Empirical Analysis from the Tsimane' in the Bolivian Amazon. Human Organization, 73(2), 162-173.

Reyes-García, V., Paneque-Gálvez, J., Bottazzi, P., Luz, A.C., Guèze, M., Macía, M.J., Orta-Martínez, M., \& Pacheco, P. (2014b). Indigenous land reconfiguration and fragmented institutions: A historical political ecology of Tsimane' lands (Bolivian Amazon). Journal of Rural Studies, 34, 282-291.

Riester, J. (1976). En busca de la Loma Santa. La Paz: Los Amigos del Libro.

Ringhofer, L. (2010). Fishing, Foraging and Farming in the Bolivian Amazon. Dordrecht: Springer.

Roca, J.L. (2001). Economía y sociedad en el oriente boliviano (siglos XVI-XX). Santa Cruz de la Sierra: Editorial Oriente.

Ross, E.B., Arnott, M.L., Basso, E.B., et al. (1978). Food Taboos, Diet, and Hunting Strategy: The Adaptation to Animals in Amazon Cultural Ecology. Current Anthropology, 19(1), 1-36. 
Salo, M., Sirén, A., \& Kalliola, R. (2014). Fishing in and Fishing out the Amazon. In M. Salo, A. Sirén, \& R. Kalliola (Eds.), Diagnosing Wild Species Harvest (pp. 93-110). London: Elsevier.

Schweitzer, P.P., Biesele, M., \& Hitchcock, R.H. (2000). Hunters \& Gatherers in the Modern World. Conflict, Resistance, and Self-Determination. New York: Berghahn Books.

Shepard Jr, G.H. (2002). Primates in Matsigenka subsistence and worldview. In A. Fuentes, \& L. Wolfe (Eds.), Primates face to face: Conservation implications of human and nonhuman primate interconnections (pp. 101-136). Cambridge: Cambridge University Press.

Undurraga, E.A., Cruz-Burga, Z., \& Godoy, R.A. (2014). Demografía y territorialidad de la población tsimane' actual. In V. Reyes-García \& T. Huanca (Eds.), Cambio global, cambio local. La sociedad tsimane' ante la globalización (pp. 91-120). Barcelona: Icaria Editorial.

Vadez, V., \& Fernández-Llamazares, Á. (2014). De la agricultura de subsistencia a la comercialización. In V. Reyes-García, \& T. Huanca (Eds.), Cambio global, cambio local. La sociedad tsimane' ante la globalización (pp. 147-175). Barcelona: Icaria Editorial.

Virtanen, P.K. (2009). Shamanism and Indigenous Youthhood in the Brazilian Amazonia. Amazônica: Revista de Antropologia, 1(1), 152-177.

Virtanen, P.K., Saarinen, S., \& Kamppinen, M. (2012). How to integrate socio-cultural dimensions into sustainable development: Amazonian case studies. International Journal of Sustainable Society, 4(3), 226-239.

Virtanen, P.K. (2016). The death of the master of peccaries: the Apurinã and the scarcity of forest resources in Brazilian Amazonia. In A. Pyhälä, \& V. ReyesGarcía (Eds.), Hunter-Gatherers in a Changing World. Springer.

Weatherhead, E., Gearheard, S., \& Barry, R.G. (2010). Changes in weather persistence: insights form Inuit knowledge. Global Environmental Change, 20(3), 523-528.

Zycherman, A. (2013). The Changing Value of Food: Localizing Modernity among the Tsimane' Indians of Lowland Bolivia. PhD Dissertation, University of Columbia. 